\title{
Optimization of Palm-Based Wax Esters Production Using Statistical Experimental Designs
}

\author{
Keng Pei Sin ${ }^{1}$, Mahiran Basri ${ }^{1 *}$, Mohd. Basyaruddin Abd. RaHMan ${ }^{1}$, \\ Abu Bakar SAlleh ${ }^{2}$, Raja Noor Zaliha Abd. RAhman ${ }^{2}$ and Arbakariya ARIFF ${ }^{2}$ \\ ${ }^{1}$ Faculty of Science, Universiti Putra Malaysia \\ (43400 UPM Serdang, Selangor, MALAYSIA) \\ ${ }^{2}$ Faculty of Biotechnology and Biomolecular Sciences, Universiti Putra Malaysia \\ (43400 UPM Serdang, Selangor, MALAYSIA)
}

Edited by K. Miyashita, Hokkaido Univ., and accepted May 31, 2005 (received for review April 21, 2005)

\begin{abstract}
Wax esters, one of the important ingredients in cosmetic industry, are longchain esters that exhibit wetting behavior with non-greasy feeling. Wax esters derived from long chain fatty acids and long chain alcohols with chain lengths of 12 carbons or more. These compounds have many potential applications in cosmetics, pharmaceutical and food industries. The present work focuses on the scale-up synthesis of wax esters by alcoholysis of palm oil (PO) with oleyl alcohol (OA) using Lipozyme in a bioreactor. Response surface methodology (RSM) and a 5-level-5-factor central composite rotatable design were adopted to evaluate the effects of synthesis parameters, such as temperature $\left(40-60^{\circ} \mathrm{C}\right)$, amount of enzyme $(14-22 \%$ by weight of PO), amount of palm oil (80-240 mmol), amount of oleyl alcohol (240-720 mmol) and impeller speed (100-400 rpm) on the percentage yield of palm-based wax esters. Based on Design Expert Software (version 6.0.4), optimum alcoholysis conditions were: temperature, $50.4^{\circ} \mathrm{C}$, amount of enzyme, $16.0 \%$ by weight of palm oil, amount of palm oil, $200.0 \mathrm{mmol}$, amount of oleyl alcohol, $600.0 \mathrm{mmol}$, palm oil/oleyl alcohol ratio, 3:1 and impeller speed, $242.1 \mathrm{rpm}$. The corresponding predicted value of percentage yield and productivity was $91.5 \%$ and $106.4 \mathrm{mmol} / \mathrm{h}$ respectively compared to the actual experimental value $92.3 \%$ yields and $110.8 \mathrm{mmol} / \mathrm{h}$ productivity.
\end{abstract}

Key words: wax ester, palm oil, Lipozyme, scale-up, alcoholysis, response surface methodology

\section{Introduction}

Palm oil is extracted from the fruit of oil palm, Elaeis guineensis. Today, palm oil is the leading agricultural crop of Malaysia, with the plantations cover $40 \%$ of its cultivated land. The production of crude palm oil in 2003 increased markedly by $12.1 \%$ or 1.4 million tonnes to 13.35 million tonnes from 11.91 million tonnes in 2002, which is the world's largest producer (1). Palm oil's unique composition makes it versatile in its application in food manufacturing and in the chemical, cosmetics as well as pharmaceutical industries.
Thus, research in development of palm oil to higher value added products is of great importance in this country.

Wax ester is a simple lipid, defined as fatty acid esters of fatty alcohols. Usually, wax esters are composed of n-alkanoic acids and n-alkan-1-ols with an even number of carbon atoms ranging from $\mathrm{C}_{12}-\mathrm{C}_{32}$ (2). Natural waxes originate from plants and animals, for example carnuba wax, jojoba oil, beeswax, spermaceti wax and many others. These high molecular weight esters are extremely stable substances and do not easily deteriorate. Carnuba wax is found on the leaves of

\footnotetext{
*Correspondence to: Mahiran BASRI, Faculty of Science, Universiti Putra Malaysia, 43400 UPM Serdang, Selangor, MALAYSIA

E-mail: mahiran@fsas.upm.edu.my
} 
Brazilian palm trees, acts as protective coating and to prevent the plant from losing excessive amounts of water; beeswax is secreted by bees to make cells for honey and eggs. While, commercial waxes have a wide range of application as lubricants, polishes, coating materials in the medical and food industries and as raw materials in cosmetics and other chemical industries (3$5)$.

Natural wax esters extracted from plant and animal sources are often in short supply and expensive. Thus, scale-up synthesis of wax esters with cheaper starting materials has become important. Wax esters can be synthesized using chemical and enzymatic methods. The use of homogenous chemical catalyst may lead to several problems such as corrosion of equipment, hazards of handling of the corrosive acids or bases, and high energy consumption as the reaction occurred at elevated temperature (6-8). On the other hand, enzymatic synthesis offers mild reaction conditions and environmental-friendly process, which have attracted attention since last decade (9-11). The specificity and selectivity of these biocatalysts are other crucial factors $(12,13)$. The alcoholysis of triacylglycerols from vegetable oils with fatty alcohols, catalyzed by lipases, leads to a mixture of long-chain wax esters with properties potentially suitable for applications in cosmetics and lubricants $(14,15)$.

In this work, the synthesis of wax esters using palm oil and long chain alcohols catalyzed by immobilized lipase from Rhizomucor miehei (Lipozyme RM IM) in a $950 \mathrm{ml}$ batch reactor was carried out. Response surface methodology (RSM), which is an efficient statistical tool for optimization of multiple variables to predict best performance conditions using a minimum number of experiments, was employed (16). It is superior to the traditional approach in which optimization studies are carried out by varying one parameter at a time while keeping others constant. The present study employs a RSM technique based on a five-level, five-variable central composite rotatable design (CCRD).

\section{Experimental}

\subsection{Materials}

\section{$2 \cdot 1 \cdot 1 \quad$ Enzyme}

Immobilized lipase (triacylglycerol hydrolase, EC 3.1.1.3; Lipozyme RM IM 150 IUN/g) from Rhizomucor miehei supported on macroporous anionic exchange resin, was purchased from Novo-Nordisk (Denmark).

\section{$2 \cdot 1 \cdot 2$ Solvent and substrates}

n-Hexane obtained from J.T. Baker (USA) was used as the organic solvent. Refined, bleached and deodorized (RBD) palm oil (MW $=3 \times$ average of saponification equivalent of palm oil) (17) was a kind gift from Southern Edible Oil Sdn. Bhd. (Malaysia). Fatty acids composition in Malaysian palm oil is $0.1-0.3 \%$ of lauric acid, $0.9-1.5 \%$ of myristic acid, $39.2-45.2 \%$ of palmitic acid, $3.7-5.1 \%$ of stearic acid, $37.5-44.1 \%$ of oleic acid and $8.7-12.5 \%$ of linoleic acid (18). Oleyl alcohol was purchased from TCI (Japan). Meanwhile, methyl linoleate, used as internal standard in gas chromatography analysis was obtained from Sigma Aldrich (USA). All chemicals were of analytical reagent grade.

\section{$2 \cdot 2$ Experimental Set-Up and Procedure}

The experimental set-up consisted of a glass flask with a capacity of $950 \mathrm{ml}$ and an inside diameter $7 \mathrm{~cm}$. A four-bladed turbine impeller $(4.5 \mathrm{~cm}$ in diameter) immersed in the solution at $2 \mathrm{~cm}$-height from the bottom of the flask was used for agitation. No baffle plates were provided. A heat exchanger was connected to water bath for temperature controlling purpose of the reaction mixture. Different amounts of oleyl alcohol and palm oil were placed in the reactor; n-hexane was added to make the final working volume of $500 \mathrm{ml}$. This was followed by adding an appropriate amount of Lipozyme RM IM. The reaction mixtures were reacted at different temperatures and impeller speeds for 5 h. 2 $\mathrm{ml}$ of the samples was withdrawn by syringe at the end of the reaction and passed through filter (syringe filter SPR 15) to remove the enzyme prior to analysis.

\subsection{Analytical Methods}

Analysis was done by injecting $1 \mu \mathrm{l}$ aliquot into a Hewlett Packard (HP) 6890 gas chromatograph in a split mode equipped with a flame-ionization detector and a RTX65 capillary column $(30 \mathrm{~m} \times 0.25 \mathrm{~mm}$ i.d.; film thickness $0.25 \mu \mathrm{m}$; Restex Corporation, USA). Injector and detector temperature were set at 250 and $300^{\circ} \mathrm{C}$, respectively. Oven temperature was maintained at $150^{\circ} \mathrm{C}$ for $2 \mathrm{~min}$, increased to $300^{\circ} \mathrm{C}$ with the ramping rate $20^{\circ} \mathrm{C} / \mathrm{min}$ and held for $14 \mathrm{~min}$. Nitrogen was used as the carrier gas with the flow rate $1.4 \mathrm{ml} / \mathrm{min}$. The product composition was quantitated by an internal standard method with methyl linoleate as the internal standard. The concentrations of esters were calculated 
by equation: $\mathrm{C}_{\mathrm{X}}=\left(\mathrm{A}_{\mathrm{X}} / \mathrm{A}_{\mathrm{IS}}\right) \times\left(\mathrm{C}_{\mathrm{IS}} \times \mathrm{D}_{\mathrm{Rf} \text { IS }} / \mathrm{D}_{\mathrm{Rf} \mathrm{X}}\right)$, where $\mathrm{C}$ is the amount of component $\mathrm{X}$ or internal standard, $\mathrm{A}$ is area for component $\mathrm{X}$ or internal standard and $D_{R f}$ is detector response factor for component $\mathrm{X}$ or internal standard $\left(D_{\mathrm{RfX}}=\mathrm{A}_{\mathrm{X}} / \mathrm{C}_{\mathrm{X}}\right.$ and $\left.\mathrm{D}_{\mathrm{Rf} I \mathrm{IS}}=\mathrm{A}_{\mathrm{IS}} / \mathrm{C}_{\mathrm{IS}}\right)$. The percentage yield of ester was calculated by equation:

$$
\begin{aligned}
\text { Percentage yield }(\%)= & (\mathrm{mmol} \text { ester } / \mathrm{mmol} \text { PO used }) \\
& \times 100 \% .
\end{aligned}
$$

Productivity $(\mathrm{mmol} / \mathrm{h})=[\mathrm{mmol}$ ester/reaction time

$$
\text { (h)] }
$$

\subsection{Effect of Time}

The effect of time on the alcoholysis reaction was investigated by using $40 \mathrm{mmol}$ of palm oil with 120 mmol of oleyl alcohol, in the presence of $400 \mathrm{ml}$ hexane and $6.00 \mathrm{~g}$ of Lipozyme. These amounts of reaction medium were 40x scale-up of the laboratory scale study (19). The reactivity was analyzed at various reaction times $(0,5,15,30,60,120,180,240,300,360,420$, $480 \mathrm{~min})$. The percentage yield was determined as described earlier.

\subsection{Experimental Design}

A 5-level-5-factor central composite rotatable design (CCRD) was employed in this study, requiring 32 experiments (20). The fractional factorial design consisted of 16 factorial points, 10 axial points (two axial points on the axis of each design variable at a distance of 2 from the design centre), and 6 centre points. The variables and their respective levels are presented in Table 1. Table 2 represents the actual experiments carried out for developing the model. The data obtained were fitted to a third-order polynomial equation (Eq. (1)):

$$
\begin{aligned}
\mathrm{Y}= & \beta_{0}+\sum_{i=1}^{5} \beta_{i} \mathrm{X}_{i}+\sum_{i=1}^{5} \beta_{i i} \mathrm{X}_{i i}^{2}+\sum_{i=1}^{5} \beta_{i i i} \mathrm{X}_{i i i}^{3}+ \\
& \sum_{i<j}^{4} \sum_{j=1}^{5} \beta_{i j} \mathrm{X}_{i} \mathrm{X}_{j}+\sum_{i<j}^{3} \sum_{j<k}^{4} \sum_{k=1}^{5} \beta_{i j k} \mathrm{X}_{i} \mathrm{X}_{j} \mathrm{X}_{k}
\end{aligned}
$$

where $\mathrm{Y}=$ wax esters formed (yield $(\%)), \beta_{0}=$ constant, $\beta_{\mathrm{i}}=$ linear term coefficients, $\beta_{\mathrm{ii}}=$ quadratic term coefficients, $\beta_{\mathrm{iii}}=$ cubic term coefficients, and $\beta_{\mathrm{ij}}$ and $\beta_{\mathrm{ijk}}$ are cross-product term coefficients. Subsequent regression analyses, analyses of variance (ANOVA) and response surfaces were performed using the Design Expert Software (version 6.0.4) from Stat-Ease Inc. (USA). Optimal reaction parameters for maximum yield were generated using the software's numerical optimization function.

\section{Results and Discussion}

\subsection{Effect of Reaction Time}

The time course of the enzymatic alcoholysis of oleyl alcohol and palm oil by Lipozyme RM IM is shown in Fig. 1. The percentage yield increased with increasing time. The reaction rate increased rapidly from $0-300$ min. After which, not much different in percent yield was observed. This may be due to an equilibrium state of the reaction where the rate of forward reaction was equal to the rate of backward reaction. In the alcoholysis reaction between oleyl alcohol and palm oil, the products are not only wax esters but also glycerol. Glycerol will be accumulated and may inhibit the reaction by limiting the interaction of the substrate and the enzyme (21). Previous work reported by Gunawan et al.

\begin{tabular}{|c|c|c|c|c|c|c|c|}
\hline \multirow[t]{3}{*}{ Variable } & & \multirow[t]{3}{*}{ Unit } & \multicolumn{5}{|c|}{ Coded levels } \\
\hline & & & -2 & -1 & 0 & 1 & 2 \\
\hline & & & \multicolumn{5}{|c|}{ Corresponding operating value } \\
\hline Temperature & $\left(\mathrm{X}_{1}\right)$ & ${ }^{\circ} \mathrm{C}$ & 40 & 45 & 50 & 55 & 60 \\
\hline Enzyme & $\left(\mathrm{X}_{2}\right)$ & $\%$ by wt. of PO & 14 & 16 & 18 & 20 & 22 \\
\hline $\mathrm{PO}$ & $\left(\mathrm{X}_{3}\right)$ & mmol & 80 & 120 & 160 & 200 & 240 \\
\hline $\mathrm{OA}$ & $\left(\mathrm{X}_{4}\right)$ & mmol & 240 & 360 & 480 & 600 & 720 \\
\hline Impeller speed & $\left(\mathrm{X}_{5}\right)$ & $\mathrm{rpm}$ & 100 & 175 & 250 & 325 & 400 \\
\hline
\end{tabular}
(19) in the laboratory scale study also showed that alcoholysis conversion from palm oil reached up to $85 \%$ in 300 min, with Lipozyme RM IM as the biocatalyst (19).

Table 1 Coded and Actual Levels of Variables for Design of Experiment. 
Hence, 300 min was chosen as the optimum reaction time in this study while varying other variables in the RSM design.

\subsection{Model Development}

The coefficients of the empirical model and their statistical analyses are evaluated using Design Expert Software $(22,23)$. In the study of scaling-up reaction, not only the percentages yield but productivity is also an

Table 2 Experimental Design of 5-level, 5-variable Central Composite Rotatable Design (CCRD).

\begin{tabular}{|c|c|c|c|c|c|c|c|c|c|}
\hline \multirow{3}{*}{ Run } & \multirow{3}{*}{$X_{1}$} & \multirow{3}{*}{$\mathrm{X}_{2}$} & \multirow{3}{*}{$X_{3}$} & \multirow{3}{*}{$\mathrm{X}_{4}$} & \multirow{3}{*}{$\mathrm{X}_{5}$} & \multirow{2}{*}{\multicolumn{2}{|c|}{$\begin{array}{l}\text { Response1 } \\
\text { Yield (\%) }\end{array}$}} & \multirow{2}{*}{\multicolumn{2}{|c|}{$\begin{array}{c}\text { Response2 } \\
\text { Productivity }(\mathrm{mmol} / \mathrm{h})\end{array}$}} \\
\hline & & & & & & & & & \\
\hline & & & & & & Actual & Predicted & Actual & Predicted \\
\hline 1 & -1 & -1 & -1 & -1 & 1 & 68.15 & 67.70 & 49.08 & 48.96 \\
\hline 2 & 1 & -1 & -1 & -1 & -1 & 71.31 & 73.18 & 51.34 & 50.32 \\
\hline 3 & -1 & 1 & -1 & -1 & -1 & 86.95 & 89.34 & 62.61 & 63.08 \\
\hline 4 & 1 & 1 & -1 & -1 & 1 & 99.02 & 100.71 & 71.30 & 72.26 \\
\hline 5 & -1 & -1 & 1 & -1 & -1 & 63.95 & 65.83 & 76.74 & 80.13 \\
\hline 6 & 1 & -1 & 1 & -1 & 1 & 63.51 & 63.06 & 76.21 & 80.08 \\
\hline 7 & -1 & 1 & 1 & -1 & 1 & 56.97 & 64.40 & 73.45 & 78.83 \\
\hline 8 & 1 & 1 & 1 & -1 & -1 & 59.08 & 55.74 & 68.37 & 72.84 \\
\hline 9 & -1 & -1 & -1 & 1 & -1 & 94.07 & 88.14 & 67.72 & 64.21 \\
\hline 10 & 1 & -1 & -1 & 1 & 1 & 81.23 & 85.37 & 58.49 & 55.47 \\
\hline 11 & -1 & 1 & -1 & 1 & 1 & 94.48 & 92.67 & 68.05 & 66.53 \\
\hline 12 & 1 & 1 & -1 & 1 & -1 & 81.35 & 84.02 & 72.65 & 70.23 \\
\hline 13 & -1 & -1 & 1 & 1 & 1 & 86.17 & 83.49 & 103.40 & 104.79 \\
\hline 14 & 1 & -1 & 1 & 1 & -1 & 88.09 & 88.97 & 105.70 & 106.18 \\
\hline 15 & -1 & 1 & 1 & 1 & -1 & 73.11 & 75.40 & 87.73 & 89.72 \\
\hline 16 & 1 & 1 & 1 & 1 & 1 & 88.20 & 86.76 & 105.83 & 108.30 \\
\hline 17 & -2 & 0 & 0 & 0 & 0 & 80.16 & 79.74 & 76.94 & 74.86 \\
\hline 18 & 2 & 0 & 0 & 0 & 0 & 84.32 & 82.45 & 80.95 & 79.72 \\
\hline 19 & 0 & -2 & 0 & 0 & 0 & 85.97 & 85.91 & 82.54 & 83.46 \\
\hline 20 & 0 & 2 & 0 & 0 & 0 & 99.59 & 94.23 & 95.61 & 91.37 \\
\hline 21 & 0 & 0 & -2 & 0 & 0 & 81.71 & 80.56 & 39.32 & 46.07 \\
\hline 22 & 0 & 0 & -2 & 0 & 0 & 78.88 & 77.73 & 113.59 & 103.52 \\
\hline 23 & 0 & 0 & 0 & -2 & 0 & 57.15 & 52.78 & 54.87 & 47.83 \\
\hline 24 & 0 & 0 & 0 & 2 & 0 & 76.91 & 78.99 & 73.84 & 77.56 \\
\hline 25 & 0 & 0 & 0 & 0 & -2 & 88.34 & 87.13 & 84.83 & 84.55 \\
\hline 26 & 0 & 0 & 0 & 0 & 2 & 96.06 & 93.01 & 92.22 & 89.18 \\
\hline 27 & 0 & 0 & 0 & 0 & 0 & 86.05 & 90.07 & 82.64 & 86.09 \\
\hline 28 & 0 & 0 & 0 & 0 & 0 & 93.66 & 90.07 & 89.92 & 86.09 \\
\hline 29 & 0 & 0 & 0 & 0 & 0 & 96.39 & 90.07 & 92.45 & 86.09 \\
\hline 30 & 0 & 0 & 0 & 0 & 0 & 80.39 & 90.07 & 79.18 & 86.09 \\
\hline 31 & 0 & 0 & 0 & 0 & 0 & 85.99 & 90.07 & 82.01 & 86.09 \\
\hline 32 & 0 & 0 & 0 & 0 & 0 & 90.55 & 90.07 & 87.03 & 86.09 \\
\hline
\end{tabular}




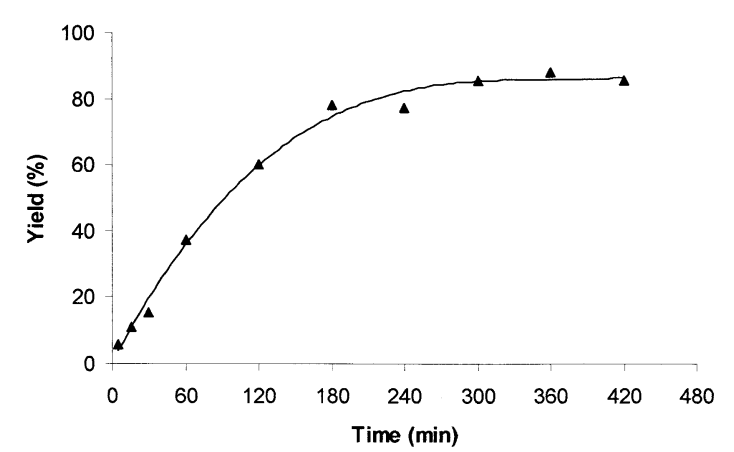

Fig. 1 Time Course Profile of Alcoholysis of Oleyl Alcohol with Palm Oil by Lipozyme RMIM. The reaction mixture consisted of $120 \mathrm{mmol}$ of oleyl alcohol, $40 \mathrm{mmol}$ of palm oil, $400 \mathrm{ml}$ of hexane, $18 \%$ (by wt. of palm oil) of Lipozyme RM IM. The reaction was carried out at $50^{\circ} \mathrm{C}, 250 \mathrm{rpm}$ of impeller speed in a bioreactor.

important criterion to be investigated. Hence, these two responses were chosen for the study in the optimization of lipase-catalyzed alcoholysis of oleyl alcohol with palm oil. The models characteristics and the coefficients are presented in Table 3 and 4, which indicate that the predictability of the model is at $95 \%$ confidence level. The models have a high $\mathrm{R}^{2}$ value, a significant $\mathrm{F}$ value, an insignificant lack-of-fit F-value and standard deviation less than 5 (Table 3). From the analysis of variance (ANOVA), the model F-values of 12.40 (yield) and 34.52 (productivity) with Prob $>$ F values $<$ 0.0001 for both of the models, implied the models were significant. The coefficients of determination $\left(\mathrm{R}^{2}\right)$ of the models were 0.9108 (yield) and 0.9660 (productivity), indicating that the models are suitable to represent the real relationships among the parameters studied. The insignificant lack-of-fit test (F-value $_{\text {(yield) }}=0.58 ; \mathrm{F}$ value $_{\text {(productivity) }}=0.58$ ) which is relative to the pure error of the experiments also indicates that the models are suitable to represent the experimental data.

Coefficients of the full model equation (1) were evaluated by regression analysis and tested for their significance. Most of the insignificant terms were eliminated on the basis of Prob $>$ F values, not counting those required to support hierarchy (all linear terms), and the models were finally refined. For the percentage yield response equation (2), it was observed that all the terms

Table 3 ANOVA and Regression Analysis of the Models.

\begin{tabular}{|c|c|c|c|c|c|}
\hline Source & Sum of squares & Degree of freedom & Mean square & F-value & Prob $>F$ \\
\hline \multicolumn{6}{|l|}{ ANOVA } \\
\hline \multicolumn{6}{|l|}{$Y_{1 \text { (yield) }}$} \\
\hline Model & 4180.20 & 14 & 298.59 & 12.40 & $<0.0001^{\mathrm{a}}$ \\
\hline Residual & 409.27 & 17 & 24.07 & & \\
\hline Lack-of-fit & 238.79 & 12 & 19.90 & 0.58 & $0.7940^{\mathrm{b}}$ \\
\hline Total & 4589.47 & 31 & & & \\
\hline \multicolumn{6}{|l|}{$\mathrm{Y}_{2 \text { (productivity) }}$} \\
\hline Model & 8901.85 & 14 & 635.85 & 34.52 & $<0.0001^{\mathrm{a}}$ \\
\hline Residual & 313.14 & 17 & 18.42 & & \\
\hline Lack-of-fit & 182.65 & 12 & 15.22 & 0.58 & $0.7943^{\mathrm{b}}$ \\
\hline \multirow[t]{2}{*}{ Total } & 9214.98 & 31 & & & \\
\hline & $Y_{1 \text { (yield) }}$ & $\mathrm{Y}_{2 \text { (productivity) }}$ & & & \\
\hline \multicolumn{6}{|l|}{ Regression statistics } \\
\hline $\mathrm{R}^{2}$ & 0.9108 & 0.9660 & & & \\
\hline Adjusted $\mathrm{R}^{2}$ & 0.8374 & 0.9380 & & & \\
\hline Standard deviation & 4.91 & 4.29 & & & \\
\hline
\end{tabular}

${ }^{a}$ Model F-value is significant at "Prob $>F$ " less than 0.05 .

${ }^{\mathrm{b}}$ Lack-of-fit value is not significant relative to the pure error. 
K.P. Sin, M. Basri, M.B.A. Rahman et al.

Table 4 Coefficients and Its Probability of a Larger F Value (Prob $>$ F) of the Models.

\begin{tabular}{lccccc}
\hline \multirow{2}{*}{ Coefficients of models } & \multicolumn{2}{c}{$\mathrm{Y}_{\text {Y Yield (\%) }}$} & & \multicolumn{2}{c}{$\mathrm{Y}_{2 \text { Productivity (mmolh) }}$} \\
\cline { 2 - 3 } \cline { 5 - 6 } Value & Prob $>\mathrm{F}$ & & Value & Prob $>\mathrm{F}$ \\
\hline Intercept & 90.07 & & 86.58 & \\
$\mathrm{X}_{1}$ & 0.68 & 0.5082 & & 1.21 & 0.1835 \\
$\mathrm{X}_{2}$ & 2.08 & 0.0533 & & 1.98 & $0.0374^{\mathrm{a}}$ \\
$\mathrm{X}_{3}$ & -7.89 & $0.0003^{\mathrm{a}}$ & & 10.16 & $<0.0001^{\mathrm{a}}$ \\
$\mathrm{X}_{4}$ & 6.55 & $<0.0001^{\mathrm{a}}$ & & 10.13 & $<0.0001^{\mathrm{a}}$ \\
$\mathrm{X}_{5}$ & 1.47 & 0.1605 & & 1.16 & 0.2041 \\
$\mathrm{X}_{1}^{2}$ & -2.24 & $0.0233^{\mathrm{a}}$ & & -2.24 & $0.0112^{\mathrm{a}}$ \\
$\mathrm{X}_{3}^{2}$ & -2.73 & $0.0075^{\mathrm{a}}$ & & -2.86 & $0.0020^{\mathrm{a}}$ \\
$\mathrm{X}_{4}^{2}$ & -6.05 & $<0.0001^{\mathrm{a}}$ & & -5.89 & $<0.0001^{\mathrm{a}}$ \\
$\mathrm{X}_{1} \mathrm{X}_{2}$ & - & - & & 1.97 & 0.0840 \\
$\mathrm{X}_{1} \mathrm{X}_{5}$ & 2.78 & $0.0369^{\mathrm{a}}$ & & - & - \\
$\mathrm{X}_{2} \mathrm{X}_{3}$ & -4.46 & $0.0020^{\mathrm{a}}$ & & -4.67 & $0.0004^{\mathrm{a}}$ \\
$\mathrm{X}_{2} \mathrm{X}_{4}$ & -2.97 & $0.0269^{\mathrm{a}}$ & & - & - \\
$\mathrm{X}_{2} \mathrm{X}_{5}$ & 3.53 & $0.0104^{\mathrm{a}}$ & 2.60 & $0.0269^{\mathrm{a}}$ \\
$\mathrm{X}_{3} \mathrm{X}_{4}$ & 4.15 & $0.0036^{\mathrm{a}}$ & 4.71 & $0.0004^{\mathrm{a}}$ \\
$\mathrm{X}_{3}^{3}$ & 1.79 & $0.0214^{\mathrm{a}}$ & 2.10 & $0.0035^{\mathrm{a}}$ \\
$\mathrm{X}_{4}^{3}$ & - & - & -1.35 & $0.0442^{\mathrm{a}}$ \\
\hline & & - & & &
\end{tabular}

a Significant at "Prob $>$ F" less than 0.05 .

are significant except the linear term for $\mathrm{X}_{1}, \mathrm{X}_{2}$ and $\mathrm{X}_{5}$. While for the productivity response equation (3), the linear terms for $\mathrm{X}_{1}$ and $\mathrm{X}_{5}$ as well as the cross-product term $X_{1} X_{2}$ were identified as insignificant as their Prob $>$ F values greater than 0.05 . The final reduced models to predict the percentage yield and productivity of alcoholysis reaction of OA with PO catalyzed by Lipozyme were as follows:

$$
\begin{aligned}
\mathrm{Y}_{1 \text { (Yield })}= & 90.07+0.68 \mathrm{X}_{1}+2.08 \mathrm{X}_{2}-7.89 \mathrm{X}_{3}+ \\
& 6.55 \mathrm{X}_{4}+1.47 \mathrm{X}_{5}-2.24 \mathrm{X}_{1}^{2}-2.73 \mathrm{X}_{3}^{2}- \\
& 6.05 \mathrm{X}_{4}^{2}+2.78 \mathrm{X}_{1} \mathrm{X}_{5}-4.46 \mathrm{X}_{2} \mathrm{X}_{3}- \\
& 2.97 \mathrm{X}_{2} \mathrm{X}_{4}+3.53 \mathrm{X}_{2} \mathrm{X}_{5}+4.15 \mathrm{X}_{3} \mathrm{X}_{4}+ \\
& 1.79 \mathrm{X}_{3}^{3}
\end{aligned}
$$

$$
\begin{aligned}
\mathrm{Y}_{2 \text { (Productivity) }}= & 86.58+1.21 \mathrm{X}_{1}+1.98 \mathrm{X}_{2}+ \\
& 10.16 \mathrm{X}_{3}+10.13 \mathrm{X}_{4}+1.16 \mathrm{X}_{5}- \\
& 2.24 \mathrm{X}_{1}^{2}-2.86 \mathrm{X}_{3}^{2}-5.89 \mathrm{X}_{4}^{2}+ \\
& 1.97 \mathrm{X}_{1} \mathrm{X}_{2}-4.67 \mathrm{X}_{2} \mathrm{X}_{3}+ \\
& 2.60 \mathrm{X}_{2} \mathrm{X}_{5}+4.71 \mathrm{X}_{3} \mathrm{X}_{4}+2.10 \mathrm{X}_{3}^{3}- \\
& 1.35 \mathrm{X}_{4}^{3}
\end{aligned}
$$

\subsection{Response Surface Plots}

The optimal levels of variables were determined by constructing three-dimensional surface plots according to equations (2) and (3). Two variables were plotted at any one time on the $\mathrm{x}_{1}$ and $\mathrm{x}_{2}$ axes, respectively, with the other three remaining variables set at their centre point values (coded level: 0 ). Figures $2 \mathrm{a}$ and $\mathrm{b}$ show the effect of enzyme amount, temperature and their mutual interaction on the percentage yield and productivity, respectively of palm-based wax esters synthesis, at 160 mmol of palm oil, $480 \mathrm{mmol}$ of oleyl alcohol and 250 rpm of impeller speed. Increase in both temperature and enzyme amount improved both yield and productivity of the reaction. However, in the percentage yield profile (Fig. 2a), an optimum point of temperature was clearly observed at $50{ }^{\circ} \mathrm{C}$. At any given enzyme amount from 16 to $20 \mathrm{wt} . \%$, the reaction yield increase with increasing temperature until $50^{\circ} \mathrm{C}$, further increase in the temperature to $60^{\circ} \mathrm{C}$ resulted in a decrease in percentage yield due to thermal degradation of the enzyme (8). Meanwhile, from Fig. 2 b a reaction with enzyme 
amount 20 wt. $\%$ and reaction temperature $55^{\circ} \mathrm{C}$ led to the maximum productivity (90\%). Higher reaction temperatures could promote collisions between enzyme and substrate molecules.

Figures 3a and b depict the interactive effect of enzyme and palm oil amount on the alcoholysis reaction in terms of percentage yield and productivity at temperature $50^{\circ} \mathrm{C}$, amount of oleyl alcohol $480 \mathrm{mmol}$ and impeller speed $250 \mathrm{rpm}$. Positive effect was observed in Fig. 3b, where increasing of enzyme and palm oil amount had led to increments in productivity. Productivity refers to amount of product that was produced in a particular reaction time. An increase of enzyme amount at any point of palm oil amount resulted in increasing of the fraction of acyl donor molecules

(a)

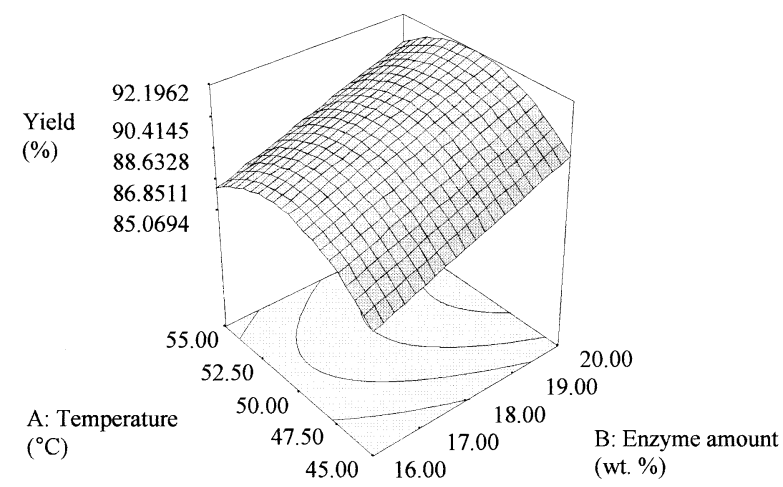

(b)

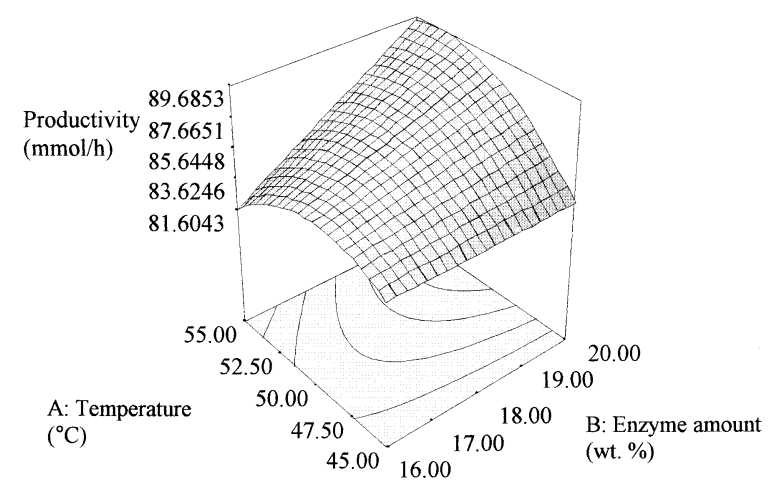

Fig. 2 Response Surface Plot Showing the Effect of Reaction Temperature and Enzyme Amount on Palm-Based Wax Esters in Terms of (a) Yield response, (b) Productivity response (Palm oil amount $=160 \mathrm{mmol}$; Oleyl alcohol $=480 \mathrm{mmol}$; Impeller speed $=250 \mathrm{rpm}$ ). that forms acyl-enzyme complexes, simultaneously increasing the amount of final product, which was in agreement with the results by Torres and Otero (24). The increment was enhanced by higher amount of substrate added. In contrast, the percentage yield was adversely affected by the present of higher amounts of palm oil. This is because the ratio of ester amount/initial amount of palm oil is lower at higher amount palm oil compared to lower amount palm oil.

Figures $4 \mathrm{a}$ and $\mathrm{b}$ represent the effect of varying reaction temperature and impeller speed on alcoholysis reaction of palm-based wax esters at enzyme amount $18 \%$ by wt. of palm oil, $160 \mathrm{mmol}$ of palm oil and 480 $\mathrm{mmol}$ of oleyl alcohol. Increasing temperature and impeller speed of the reaction led to an increase in both

(a)

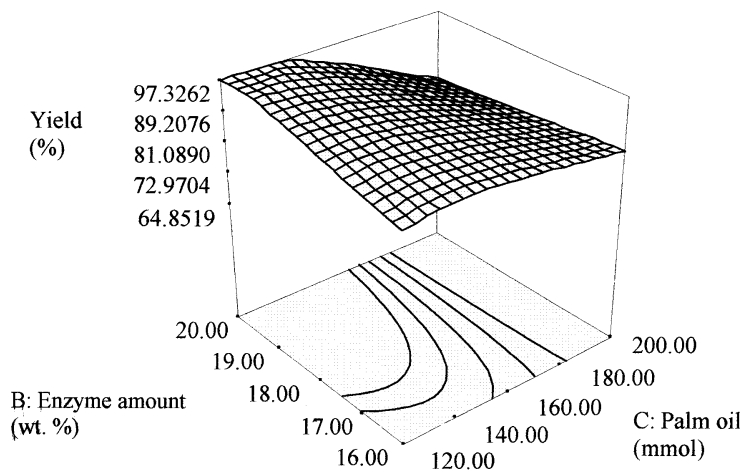

(b)

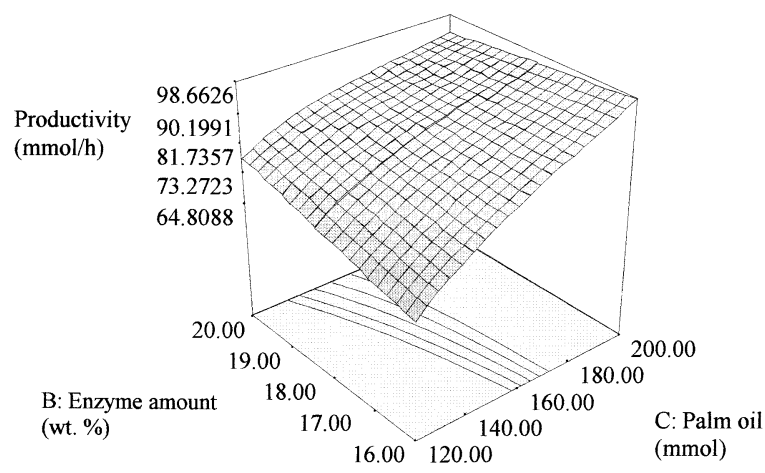

Fig. 3 Response Surface Plot Showing the Effect of Enzyme Amount and Palm Oil Amount on Palm-Based Wax Esters Synthesis in Terms of (a) Yield response, (b) Productivity response (Temperature $=50^{\circ} \mathrm{C}$, Oleyl alcohol $=480 \mathrm{mmol}$; Impeller speed $=250 \mathrm{rpm}$ ). 
(a)

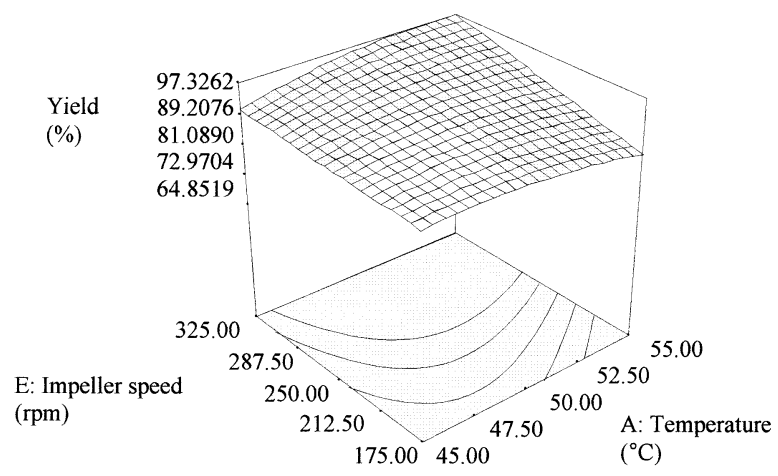

(b)

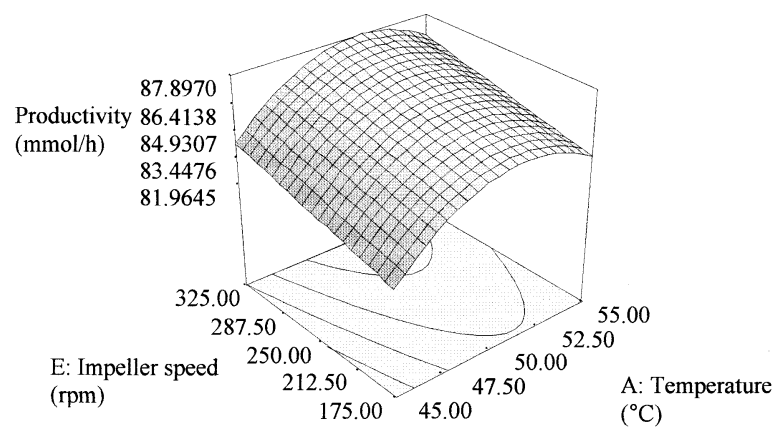

Fig. 4 Response Surface Plot Showing the Effect of Reaction Temperature and Impeller Speed on PalmBased Wax Esters Synthesis in Terms of (a) Yield response, (b) Productivity response (Enzyme amount $=18$ wt. $\%$ of palm oil; Palm oil $=160$ mmol; Oleyl alcohol $=480 \mathrm{mmol}$ ).

responses. However a decrease in productivity was observed when the reaction temperature exceeded $50^{\circ} \mathrm{C}$, this is due to the denaturation of enzyme at higher temperature. Similar trend was reported by Chiang et al. (25). Al-Zuhair et al. (2002) in their study of enzymatic hydrolysis of palm oil by lipase reported that increasing the agitation speed would result in increased total interfacial area (26). This observed effect of agita- tion speed is due to increase in shear rate on the oil droplets with increasing agitation speed that caused the breakage of the larger oil droplets into smaller ones. Meanwhile, increasing temperature also resulted in a decrease oil droplets size, which might be due to reduction in viscosity of the oil and the surface tension at interface between solvent and oil (27).

\section{$3 \cdot 4$ Optimization of Reaction}

Within the experimental range studied, optimal conditions for the Lipozyme-catalyzed production of palmbased wax esters were predicted using optimization function of the Design Expert Software. The optimal conditions are presented in Table 5 along with their actual and predicted values. Comparison of predicted and experimental values revealed good correspondence between them, implying that empirical models derived from RSM can be used to adequately describe the relationship between the factors and responses in Lipozyme-catalyzed production of palm-based wax esters. The optimal $\mathrm{PO} / \mathrm{OA}$ ratio for the alcoholysis reaction is 3:1. Similar result was obtained in the laboratory scale synthesis (19). Steinke et al. (2001) reported that lipase-catalyzed esterification of stoichiometric mixtures of long-chain and very long-chain fatty acids with the corresponding mixture of alcohols gave quantitative yields of wax esters (28). Excess of oleyl alcohol in the reaction mixture may lead to decreasing yield due to the distortion of the essential water layer by the excessive alcohols, which stabilizes the immobilized enzyme, resulted in the inhibition of the enzyme activity (29).

Lipozyme can work well up to temperature of $70^{\circ} \mathrm{C}$ as reported by the manufacturer. Many reactions were undertaken at temperature range $30-70^{\circ} \mathrm{C}$ to test for its performance. A different optimal temperature was observed depending on the reaction conditions $(14,30$, 8). A temperature of $50^{\circ} \mathrm{C}$ was sufficient to produce high yield $(>90 \%)$ in lipase-catalyzed alcoholysis of palm-based wax esters. Higher value of temperature will only cause high energy consumption and evapora-

Table 5 Optimal Conditions of Palm-Based Wax Esters Synthesis by RSM.

\begin{tabular}{|c|c|c|c|c|c|c|c|c|}
\hline \multicolumn{5}{|c|}{ Optimal conditions } & \multicolumn{2}{|c|}{ Actual value } & \multicolumn{2}{|c|}{ Predicted value } \\
\hline $\begin{array}{l}\mathrm{X}_{1} \\
\left({ }^{\circ} \mathrm{C}\right)\end{array}$ & $\begin{array}{c}\mathrm{X}_{2} \\
\text { (wt. \%) }\end{array}$ & $\begin{array}{c}\mathrm{X}_{3} \\
(\mathrm{mmol})\end{array}$ & $\begin{array}{c}\mathrm{X}_{4} \\
(\mathrm{mmol})\end{array}$ & $\begin{array}{c}\mathrm{X}_{5} \\
(\mathrm{rpm})\end{array}$ & $\begin{array}{l}\text { Yield } \\
(\%)\end{array}$ & $\begin{array}{l}\text { Productivity } \\
(\mathrm{mmol} / \mathrm{h})\end{array}$ & $\begin{array}{l}\text { Yield } \\
(\%)\end{array}$ & $\begin{array}{c}\text { Productivity } \\
(\mathrm{mmol} / \mathrm{h})\end{array}$ \\
\hline 50.43 & 16.01 & 200.00 & 600.00 & 242.10 & 91.47 & 106.43 & 92.29 & 110.76 \\
\hline
\end{tabular}


tion of n-hexane (boiling point of n-hexane $=68^{\circ} \mathrm{C}$ ). Meanwhile, in the batch reactor system where enzyme is in suspension, the quality of this suspension and partition of substrates around the enzyme particle is dependent on agitation. Increasing the agitation speed will increase the reaction yield as it promotes collisions between enzyme and substrate molecules. However, when the speed had exceeded the optimal point, the reaction yield decreased, possibly due to the shearing of the enzyme molecule (8). Therefore, an optimal agitation speed was obtained at $242 \mathrm{rpm}$.

\section{Conclusion}

In summary, the models of yield and productivity response were generally similar. A set of optimal reaction conditions was obtained with compromise of these two responses: temperature, $50.4^{\circ} \mathrm{C}$, amount of enzyme, $16.0 \%$ by weight of palm oil, amount of palm oil, 200.0 mmol, amount of oleyl alcohol, $600.0 \mathrm{mmol}$, palm oil/oleyl alcohol ratio, 3:1 and impeller speed, 242.1 rpm. A further study regarding mixing process in the bioreactor will be conducted prior scaling-up to larger volume production of palm-based wax esters.

\section{Acknowledgements}

This project was financed by a grant from IRPA Project, No. 01-02-04-0000-PR0013/01. The authors also would like to thank the Ministry of Science, Technology and Innovation (MOSTI) of Malaysia for the scholarship awarded to Keng Pei Sin.

\section{References}

1. MALAYSIA PALM OIL BOARD, Overview of the Malaysian Oil Palm Industry 2003, Palm Oil Update, Vol. 24(1/04), i-iii (2004).

2. S. MISRA and A. GHOSH, Analysis of Epicuticular Waxes, in Essential Oils and Waxes (H.F. LINSKENS and J.F. JACKSON, ed.), Springer-Verlag Berlin Heidelberg, New York, pp. 205-229 (1991).

3. J.P. CHEN and J.B. WANG, Wax Ester Synthesis by Lipase-Catalyzed Esterification with Fungal Cells Immobilized on Cellulose Biomass Support Particles, Enz. Microb. Technol., Vol. 18, 615-622 (1997).

4. M.L. HALlBERG, D. WANG and M. HARROD, Enzymatic Synthesis of Wax Esters from Rapeseed Fatty Acid Methyl Esters and Fatty Alcohol, J. Am. Oil Chem. Soc., Vol. 76(2), 183-187 (1999).
5. T.R. PETER and B. ROBERT, Beeswax through the Ages, Personal Care, Vol. 10, 27-31 (2001).

6. U. SCHUCHARDT, R. SERCHELI and R.M. VARGAS, Transesterification of Vegetable Oils: A Review, J. Braz. Chem. Soc., Vol. 9(1), 199-210 (1998).

7. G. STEINKE, R. KIRCHHOFF and K.D. MUKHERJEE, Alkali-Catalyzed Alcoholysis of Crambe Oil and Camelina Oil for the Preparation of Long-Chain Esters, J. Am. Oil Chem. Soc., Vol. 77(4), 367-371 (2000).

8. G.D. YADAV and P.S. LATHI, Kinetics and Mechanism of Synthesis of Butyl Isobutyrate over Immobilized Lipases, Biochem. Eng. J., Vol. 16, 245-252 (2003).

9. M. TRANI, F. ERGAN and G. ANDRÉ, Lipase-Catalyzed Production of Wax Esters, J. Am. Oil Chem. Soc., Vol. 68(1), 20-23 (1991).

10. G. STEINKE, R. KIRCHHOFF and K.D. MUKHERJEE, Lipase-Catalyzed Alcoholysis of Crambe oil and Camelina Oil for the Preparation of Long-Chain Esters, J. Am. Oil Chem. Soc., Vol. 77(4), 361-366 (2000).

11. A. SALIS, V. SOLINAS and M. MONDUZZI, Wax Esters Synthesis from Heavy Fraction of Sheep Milk Fat and Cetyl Alcohol by Immobilized Lipases, J. Mol. Catalys. B: Enz., Vol. 21, $167-$ 174 (2003).

12. N.N. GANDHI, Applications of Lipase, J. Am. Oil Chem. Soc., Vol. 74(6), 621-634 (1997).

13. P.E. SONNET, Lipase Selectivities, J. Am. Oil Chem. Soc., Vol. 65(6), 900-904 (1988).

14. M. MITTELBACH, Lipase Catalyzed Alcoholysis of Sunflower Oil, J. Am. Oil Chem. Soc., Vol. 67(3), 168-170 (1990).

15. B.K. DE, D.K. BHATTACHARYYA and C. BANDHU, Enzymatic Synthesis of Fatty Alcohol Esters by Alcoholysis, J. Am. Oil Chem. Soc., Vol. 76(4), 451-453 (1999).

16. D.C. MONTGOMERY, Design and Analysis of Experiments, 5th edn., John Wiley \& Sons Inc., New York, (1997).

17. L.V. COCKS and C.V. REDE, Laboratory Handbook for Oil and Fats, 3rd edn., Academic Press, London and New York, pp. 118-119 (1976).

18. PORIM Technology, Malaysian Palm Oil Chemical and Physical Characteristic, Bangi: Palm Oil Research Institute Malaysia, Vol. 3, 2 (1981).

19. E.R. GUNAWAN, M. BASRI, M.B.A. RAHMAN, A.B. SALLEH and R.N.Z.A. RAHMAN, Lipase-Catalysed Synthesis of Palm-Based Wax Esters, J. Oleo Sci., Vol. 53, 471-477 (2004)

20. Design Expert Version 6.0.4. User's Guide, Section 12, StatEase Inc., USA, (2002).

21. B. DECAGNY, S. JAN, J.C. VUILLEMARD, C. SARAZIN, J.P. SEGUIN, C. GOSSELIN, J.N. BARBOTIN and F. ERGAN, Synthesis of Wax Ester through Triolein Alcoholysis: Choice of the Lipase and Study of Mechanism, Enz. Microb. Technol., Vol. 22, 578-582 (1998)

22. E.L. SOO, A.B. SALLEH, M. BASRI, R.N.Z.A. RAHMAN and K. KAMARUDDIN, Response Surface Methodological Study on Lipase-Catalyzed Synthesis of Amino Acid Surfactants, Pro- 
cess Biochem., Vol. 39, 1511-1518 (2003).

23. N.N. NAWANI and B.P. KAPADNIS, Optimization of Chitinase Production Using Statistics Based Experimental Designs, Process Biochem., Vol. 40, 651-660 (2005).

24. C. TORRES and C. OTERO, Part III. Direct Enzymatic Esterification of Lactic Acid with Fatty Acids, Enz. Microb. Technol., Vol. 29, 3-12 (2001).

25. S. CHANG, J. SHAW and C. SHIEH, Optimization of Enzymatically Prepared Hexyl Butyrate by Lipozyme IM-77, Food Technol. Biotechnol., Vol. 41(3), 237-242 (2003).

26. S. AL-ZUHAIR, M. HASAN and K.B. RAMACHANDRAN, Kinetics Hydrolysis of Palm Oil by Lipase, Process Biochem., Vol. 38, 1155-1163 (2003).
27. S.W. TSAI and C.S. CHANG, Kinetics of Lipase Catalyzed Hydrolysis of Lipids in Biphasic Organic-Aqueous Systems, $J$. Chem. Technol. Biotechnol., Vol. 57, 147-154 (1993).

28. G. STEINKE, P. WEITKAMP, K. KLEIN and D. MUKHERJEE, High Yield Preparation of Wax Esters via Lipase-Catalyzed Esterification Using Fatty Acids and Alcohols From Crambe and Camelina Oils, J. Agric. Food Chem., Vol. 46, 647-651 (2001).

29. B. SELMI and D. THOMAS, Immobilized Lipase-Catalyzed Ethanolysis of Sunflower Oil in a Solvent-Free Medium, J. Am. Oil Chem. Soc., Vol. 73, 1191-1195 (1996).

30. V. DOSSAT, D. COMBES and A. MARTY, Lipase-Catalyzed Transesterification of High Oleic Sunflower Oil, Enz. Microb. Technol., Vol. 30, 90-94 (2002). 